\title{
REFLECTIONS
}

\section{The Island}

Peter A. Selwyn, MD, MPH

Montefiore Medical Center, Albert Einstein College of Medicine, Bronx, New York
Conflict of interest: none reported

\section{CORRESPONDING AUTHOR}

Peter A. Selwyn, MD, MPH

Department of Family and Social Medicine Montefiore Medical Center

Albert Einstein College of Medicine

3544 Jerome Ave

Bronx, NY 10467

selwyn@aecom.yu.edu

\begin{abstract}
A clinician's chance encounter on the subway, after a long day seeing patients, prompts reflections on the nature of our interactions with our patients and with others we come across in our lives. Random yet precise, these interactions create a string of opportunities to witness other people's lives as well as our own. Sitting next to a young girl and her mother, the author daydreams about the images that appear to be on the surface, and then suddenly glimpses another level of reality that redefines the stereotypes. Like strangers on a train, we accompany our patients, everyone with their own stories and histories, in a series of unique moments. Occasionally a door opens that lets us see things differently. If we are receptive to it, we may learn something not only about our patients but also about ourselves.
\end{abstract}

Ann Fam Med 2008;6:78-79. DOI: 10.1370/afm.763.

S itting on the subway on a summer evening, heading downtown from a long day of seeing patients in the Bronx, and immersed in the careless proximity of my fellow travelers, I am struck by the random precision of this moment. A group of more than 100 people share a subway car from one stop to the next, all with our own unique histories and life paths, brought together for this instant, and then will never be together again. I also find my mind wandering over the steady stream of patients I had just seen that day in our health center, all with their own stories and life details, with whom I had shared a succession of moments, both unique and routine.

People jostle up against each other in the crowded car, pushed unavoidably by the rocking and pitching of the train, a fragrant mix of smells, sounds, and images. It feels good to be surrounded by such a vibrant, anonymous mix of strangers. I start daydreaming about the lives and stories of the people all around me. The little girl to my left, about 8 years old, I think, makes me remember my own daughters at her age, hair tightly pulled back in two pony tails with Little Mermaid hair bands, pink-striped sneakers with a cartoon character painted on them that I don't recognize. Wearing blue jeans and a shiny, brightly colored Dora the Explorer plastic backpack, the little girl pulls at her mother's shirt, fussing and whining quietly, prompting just a cursory response from her mother who is preoccupied talking on her cell phone. "I don't care what they tell me, if I have a sick day and I am going to lose it, then I'm going to use it, give me a break! That bitch, I'll show her who she is messing with, I'm not going to put up with her business, I need that job, even though the pay sucks. Ain't no one else bringing in any money right now," she snorts as an aside.

She looks tired, in her late 20's, I guess, with heavy mascara, lipstick, and dyed reddish hair, and a couple of heavy gold chains around her neck. "I'm too tired to keep doing this," she sighs to her friend, "I just want to go home and chill," then gives her daughter a small bag of potato chips, telling her that if she doesn't keep quiet and stop whining she won't get a soda when they get off the train. The little girl quiets down immediately, eating the chips solemnly, one by one. She swings her legs back and forth on the plastic subway seat, her mother absently reaching over to keep her 
from kicking too far out in front of her to avoid hitting one of the standing passengers in front of us. "Why don't you come over later, bring a six-pack, I'll need it!" the mother laughs, then goes into an animated aside with her friend about another friend of theirs who had just hooked up with a guy from the neighborhood, who they both agreed was really hot. The little girl has almost finished her chips, looking up intermittently at her mother as if to make sure she is doing an adequately quiet job with the chips to still get the soda. The mother doesn't seem to notice.

I sit observing the interaction between the girl and her mother, as I might in an examination room. I make a series of quick judgments about what is lacking in this dyadic bond, about what type of role model the mother is. I think of how narcissistic and self-absorbed she must be, how the little girl may be suffering as a result, and so on. Then the mother says, still talking to her friend on the cell phone, "Well, it's about 5:30 now, by the time we get to the Island it'll be 6:30 if we don't have to wait for the next train, then they make you go through intake and processing, and then you gotta wait in the visiting area for them to come out. Probably won't get to see him till after 7 , then we can stay an hour, and by the time we get home it'll probably be about 10 , so why don't you come by after that? I could use a visit."

I stop to consider how what I have just heard immediately transforms the stereotypes I had so easily conjured. The little girl and her mother were going to see their father-husband at Rikers Island, the municipal jail for New York City. Rikers is a small island just off La Guardia Airport with a huge jail complex that has more than 100,000 inmate admissions per year. They are taking the subway to see daddy in jail, just as another subway ride downtown might take this young family to the Disney Store or Central Park. What has this meant for the little girl? How has it already challenged the mother's coping skills and resources? Will the father be able to get a job when he gets out, or is this the beginning of what often becomes a downward spiraling pathway that will further marginalize him, jeopardize the stability of the family, and alter the life path of the little girl? I suddenly want to shield her from the harshness of this reality. I picture her Little Mermaid hair bands against the thick gray bars and barbed wire of the prison. I ask myself, rhetorically, why does this little girl have to be exposed to the grim mechanics of a sprawling, urban jail in the far reaches of the city? Why is this the reality that she and her mother must navigate on this languid summer evening? And then the doors open at 42 nd Street, the young woman grabs the little girl's hand, and they hurry off the train. Other people get up and leave, new ones enter. The mix changes, and the train continues downtown with 100 new faces, stereotypes, and realities

The train rumbles through the dark tunnel, lights flashing through shadows, everyone swaying together, and I suddenly feel open, aware of all the stories and history that lie just beneath the surface of perception. I also think back again over all the patients I have seen this day, about how both they and I come to our brief encounters with our own experience, baggage, and secrets. Each time I sit with a patient, it is as if everything in both of our lives has brought us to this exact moment, which can be an opportunity for the mundane or, at times, the almost sacred. Sometimes we connect only briefly, or perhaps miss each other's meaning, and continue superficially through our daily routine. But sometimes, when a certain question, phrase, or gesture opens a door, we may have a glimpse into a whole new room that is suddenly open to light and understanding. Like a glance in a crowd between strangers, sometimes everything aligns, the extraneous is stripped away, and we can look deeply into someone's soul. Random yet precise, a series of interactions, of fleeting moments that occasionally verge on timelessness. These moments can't be forced or created; the best we can do is to learn to witness, patiently, with humility, and not let ourselves or our judgments get in the way of the process - to learn to be present, attentive, and open to the story that is waiting to be told.

In my mind, I silently wish the little girl and her mother safe passage as they move through the different worlds that they must traverse. I hope, perhaps unrealistically, that they will soon be reunited at home with their father-husband who remains, for now, on the Island. But then I realize it is too early to envision such a happy ending for this work in progress; that part still needs to be written. I get up to leave the train at 14 th Street and am greeted by a phalanx of people waiting on the platform, ready to take their places on the train. The wave of summer heat hits me, sweet and dense and hanging heavily in the station. The train's doors close as I make my way up the stairs against the flow of people coming down, and I watch as it picks up speed and rattles down the platform through the tunnel and beyond.

To read or post commentaries in response to this article, see it online at http://www.annfammed.org/cgi/content/full/6/1/78.

Key words: Physician-patient communication

Submitted April 18, 2007; submitted, revised, July 17, 2007; accepted July 24, 2007. 